\title{
O DIREITO DOS ÍNDIOS NO BRASIL: A TRAJETÓRIA DOS GRUPOS INDÍGENAS NAS CONSTITUIÇÕES DO PAÍS
}

DANIELLE BASTOS LOPES ${ }^{1}$

UERJ

\begin{abstract}
RESUMO: Nosso artigo apresenta a representação das culturas indígenas na história das constituições do país. Neste caso, é interessante observar que desde a primeira Carta Magna, a "Constituição do Império do Brasil”, outorgada por Dom Pedro I em março de 1824, até a atual Carta de 1988, os índios foram considerados para o Estado como uma categoria transitória, período no qual era obrigatória a "integração dos silvícolas à comunhão nacional”. Somente com a Constituição de 1988, promulgada após um período de fechamento político, é que os direitos indígenas foram inscritos pela primeira vez numa constituição federal. Neste caminho, debruçamo-nos em perguntas sobre: Como foi o processo de construção da nova Constituição? Houve, de fato, alguma influência do movimento indígena em seu texto final? Em síntese, a consequência da trajetória dos direitos indígenas ao longo da história é o nosso objetivo central. Para tanto, estivemos nos arquivos do Congresso Nacional e demais arquivos nacionais. As fontes encontradas dentro do Congresso muitas vezes estiveram misturadas a outros segmentos; sendo assim, foi preciso selecionar as partes destinadas aos povos indígenas dentro das atas e relatórios, e buscar, nos relatos orais de um dos participantes, Álvaro Tukano, liderança do movimento indígena, e do jornalista José Ribamar Bessa Freire, as memórias do período.
\end{abstract}

PALAVRAS-CHAVE: Direitos indígenas; Movimento Indígena; Constituição Brasileira.

ABSTRACT: Our article presents the representation of indigenous cultures in the history of the constitutions of the country. It's worth highlighting that since Brazil's first Magna Carta -"Constituição do Império do Brasil", granted by Dom Pedro I on March 1824 -- until the 1988 Constitution, currently in effect, indigenous people were considered by the state as a transitory category, during which integration to the national community was mandatory. The 1988 Constitution, enacted after a period of political closure, was the first to dispose about indigenous rights. Therefore, we work with the following questions: How was the process of establishing the new constitution? Did the Indigenous Movement have actual influence over the final text? I.e., our main goal is to investigate the results of the trajectory of indigenous rights throughout history. In order to do so, we visited the National Congress archives and others archives. The researched files often embodied other subjects, so it was necessary to screen proceedings and reports to find the sections about indigenous peoples. In interviews with Álvaro Tukano (indigenous leader) and the journalist José Ribamar Bessa Freire we sought memories of the period.

${ }^{1}$ Doutoranda no Programa de Pós Graduação em Educação da UERJ (PROPED - UERJ) -Universidade do Estado do Rio de Janeiro; Mestre em História Social pelo PPGMS -UERJ. Pesquisadora do grupo Currículo, Cultura e Diferença coordenado pela professora Dr. Elizabeth Fernandes Macedo. E-mail: daniellebastoslopes@ hotmail.com .

Espaço Ameríndio, Porto Alegre, v. 8, n. 1, p. 83-108, jan./jun. 2014. 
KEYWORDS: Indigenous Rights; Indigenous Movement; Brazilian Constitution.

Não me queriam deixar entrar no Congresso. Pediram documento. Minha orelha furada - esse é o documento (RAONI MENTUKTIRE apud LACERDA, 2008, p. 206) ${ }^{2}$.

\section{Introdução}

Quando vasculhamos dentro dos estudos históricos, ainda nas primeiras décadas do século passado, podemos observar que a questão indígena esteve quase sempre centrada no período colonial, poucas eram as áreas em exceção à Antropologia que analisavam o índio em seu aspecto contemporâneo. A partir dos anos 70, com o alargamento do interesse sobre a chamada "História dos Vencidos" - a história dos povos colonizados, como a dos povos africanos, comunidades quilombolas e, por sua vez, das sociedades ameríndias -, foram ganhando novas pesquisas e mais espaço no meio acadêmico. Seguindo esta abertura, apresentamos um estudo sobre as questões indígenas em seu aspecto contemporâneo, analisando a influência da participação indígena no processo de construção da atual Constituição, ocorrido nos anos 80 em contexto de (re)abertura democrática, após aproximadamente duas décadas de fechamento político em um governo ditatorial.

Ao analisar brevemente a legislação indigenista inscrita nas constituições anteriores, percebemos que durante 500 anos o Estado colonial português, e depois o imperial e republicano, considerou as etnias indígenas como categorias transitórias ou em extinção (PACHECO DE OLIVEIRA, 2006, p. 25). Com a promulgação da Constituição de 1988 esse quadro muda expressivamente, e a partir de sua promulgação os índios passam a ter direitos sobre a terra, a língua, a educação e a

\footnotetext{
${ }^{2}$ Fala de Raoni Mentukire na Assembleia Nacional Constituinte de 1988.
} 
cultura. Neste caminho, debruçamo-nos sobre as perguntas: Como foi o processo de construção da nova Carta? Houve, de fato, alguma influência indígena em seu texto final? Se houve, quais foram as influências dos índios neste processo? Em síntese, a consequência da participação indígena no processo Constituinte é o nosso objetivo central.

Para buscar respostas para essas questões, estivemos nos arquivos do Congresso Nacional e na sede da FUNAI (Fundação Nacional do Índio) em Brasília. As fontes encontradas dentro do Congresso localizam-se misturadas a outros segmentos, como a questão do negro e do deficiente físico e mental, uma vez que os três grupos foram votados em uma mesma Comissão Temática. Sendo assim, foi preciso selecionar as partes mais importantes destinadas aos povos indígenas dentro das atas, relatórios e regimentos internos; e buscar, nos relatos orais de um dos participantes, Álvaro Tukano, liderança do movimento União das Nações Indígenas, e no relato do jornalista José Ribamar Bessa Freire, as memórias do período.

O primeiro entrevistado é pertencente à etnia Tukano, viveu até os vinte anos numa aldeia chamada São Francisco, no Alto Rio Negro, no município de São Gabriel da Cachoeira. Saiu de sua aldeia para poder continuar os estudos na capital. Juntamente com outros índios estudantes da UNB (Universidade Nacional de Brasília), formou a primeira entidade indígena organizada pelos próprios índios, a União das Nações Indígenas (UNI), e foi também responsável pela participação indígena na Constituinte. Nestes termos, a União das Nações Indígenas é considerada a pioneira no que intitulamos nesta pesquisa como: "movimento social indígena".

O segundo entrevistado é José Ribamar Bessa Freire, jornalista responsável pela criação do jornal Porantim (o primeiro a realizar matérias exclusivamente relativas aos índios no país) e presidente do Partido dos Trabalhadores no Amazonas (PT - Amazonas). O periódico cobriu não só o processo de criação do movimento indígena, como todos os acontecimentos ocorridos no período Constituinte.

A partir das entrevistas, foi possível relacionar o relato das fontes orais com o material encontrado no Congresso e demais obras bibliográficas. Todavia, outras fontes, como a entrevista dos 
congressistas, setores de grupos opositores à participação dos índios na Constituinte, ou mesmo a entrevista de um maior número de representantes indígenas, não puderam ser esgotadas neste trabalho. No entanto, neste esforço, este artigo dividiu-se nas seguintes partes: (1) no primeiro momento realizamos uma breve trajetória histórica da representação dos povos indígenas nas constituições do país; (2) no segundo, estudamos as bases sobre como se deram as políticas indigenistas e sua relação com os militares; (3) num terceiro momento analisamos a criação do movimento indígena no Brasil e sua relação com setores considerados mais "progressistas" da Igreja Católica; e, (4) por fim, na última parte, debruçamo-nos sobre a análise da participação indígena e seus aliados na elaboração do texto constitucional final de 1988.

\section{A trajetória histórica do termo "índio" nas constituições do Brasil}

Neste sentido, logo num primeiro momento, quando estudamos a trajetória das constituições brasileiras, nos deparamos com as ausências e limitados espaços para a representação dos grupos indígenas. Ainda que nos escritos de Caminha os índios tenham sido narrados em uma descritividade quase mística, desde então as Cartas brasileiras ao longo dos séculos cederam poucas linhas para tratar destes habitantes mais antigos.

No período colonial, por exemplo, ao analisarmos brevemente sua legislação, é notória a diferenciação feita pela Coroa Portuguesa entre duas categorias: os índios amigos ou ditos aliados e os inimigos ou bravos (BEOZZO, 1983). Os primeiros eram os índios que atendiam aos interesses da Coroa e trabalhavam como escravos para as colônias, e os segundos eram os resistentes à catequese e à "civilização" ${ }^{\text {. Em relação }}$ aos índios "amigos", havia uma política intitulada como "descimento". O descimento era o processo de persuasão dos índios, sem a utilização de "violência", a se deslocarem de suas terras originais para as aldeias

\footnotetext{
${ }^{3}$ A ideia de "civilização" consistia na apropriação do modo de vida e conduta referente aos colonos. As culturas indígenas deveriam afastar-se do estado "selvagem", "silvícola". Era a função da Igreja e, sobretudo, do modelo missionário exercer a função de doutrinação e afastamento dessas comunidades do caráter "selvagem" na sociedade colonial (BEOZZO, 1983, p. 123).
} 
localizadas na cercania das colônias portuguesas, isto é, os aldeamentos propriamente ditos. A política se justificava pelo processo de "civilização dos indígenas", bem como pela necessidade de disponibilizar o acesso à mão de obra. Os descimentos foram incentivados e constantes desde o Regimento de Tomé de Sousa, de 1547, até o Diretório Pombalino de 1757. A "liberdade" foi garantida em todo período colonial aos índios aldeados e amigos, mas a "não escravidão" concedida era dada desde que os índios "gentios" trabalhassem em um sistema de trabalho compulsório, sem revelia ou contestação aos colonos.

A escravidão de índios, para ser considerada lícita era somente permitida como consequência da "Guerra Justa". A Guerra Justa repercutia em momentos de ampla violência, onde era discutido o que deveria ser justo ou não justo para captura de um selvagem. O que se sabia era que o justo era capturar os índios "não amigos". Em oposição e retaliação aos abusos cometidos na colônia brasileira, foram decretadas as grandes Leis de liberdade (em 1609, 1680 e 1755), onde a Coroa não fazia distinção entre amigos $\mathrm{e}$ inimigos, atingia a todos indiscriminadamente (BEOZZO, 1983).

No entanto, cabem duas observações sobre o contexto histórico destas leis: a primeira é a necessidade de mão de obra barata para o bom andamento das propriedades coloniais; a segunda é o monopólio, pela Coroa, do tráfico negreiro, em curso, que se confrontava com a escravidão indígena - em outras palavras, era a substituição da escravidão indígena pela escravidão negra.

Entrando no século XIX, o vemos marcado por uma heterogeneidade em vários aspectos: é o único que vivencia três regimes políticos (Colônia, Império e República) e o primeiro a ganhar uma Carta Magna Brasileira. A primeira, a Constituição do Império do Brasil, foi outorgada por Dom Pedro I em 24 de março de 1824; e, assim como as seguintes, não teve participação popular para sua promulgação, foi omissa em relação aos povos indígenas e somente no Ato Adicional de 1834 dispunha que: "entre as competências legislativas das províncias, obtém a tarefa de catequese e civilização dos indígenas" (CF., 1824, art. 11, p. 5).

De acordo com Rosane Lacerda (2008, p. 13), havia duas correntes de opinião em relação à temática indígena no século XIX, já 
que a mesma se encontrava ausente do texto constitucional do Império. Tínhamos, de um lado, Francisco Adolfo Varnhagem (1806-1878), o Visconde de Porto Seguro, que defendia a necessidade da sujeição dos índios à força brasileira em benefício da consolidação das fronteiras do Império. E, do outro, José Bonifácio de Andrada e Silva (1763-1838), autor do documento Apontamentos para a Civilização dos Índios Bravos do Brasil, que defendia a obrigação moral do Império em prover-Ihes condições para seu ingresso no projeto de unidade nacional. O artigo foi proposto como contribuição à Carta de 1824, mas nunca acrescentado. É curioso observar que ainda com algumas discordâncias em relação à política mais agressiva de Varnhagem e outra mais protecionista de Bonifácio, ambos comungavam da mesma ideia de certa "inferioridade silvícola".

Anos mais tarde, a Constituição Republicana de 1891 e seu apostolado positivista também não relatou qualquer citação sobre a existência dos povos indígenas em suas páginas. Os anseios por um Brasil progressista e pela república que se buscava construir eram latentes na depreciação do índio. Um forte exemplo desse ideário foi expresso ainda nos primeiros anos de República, em 1900, na comemoração do "Quarto Centenário do Descobrimento do Brasil" (BESSA FREIRE, 2009). Realizado no Rio de Janeiro, então capital do país, o discurso republicano proferido por André Gustavo Paulo Frontin 4 (1860-1933) na abertura de cerimônia da Sessão Magna representou claramente essa ideia de rejeição. Em seu discurso original, Frontin proferia:

O Brasil não é o índio; este, onde a civilização ainda não se extendeu perdura com os seus costumes primitivos, sem adeantamento nem progresso. Descoberto em 1500 pela frota portugueza ao mando de Pedro Alvares Cabral, o Brasil é a resultante directa da civilização occidental, trazida pela immigração, que lenta, mas continuadamente, foi povoando o solo. (...) Os selvícolas, esparsos, ainda abundam nas nossas magestosas florestas e em nada differem dos seus antecedentes de 400 anos atrás; não são nem podem ser considerados parte integrante de nossa nacionalidade; a esta cabe assimilá-los e, não

\footnotetext{
${ }^{4}$ Paulo Frontin (1860-1933) se tornou, em 1919, prefeito da cidade do Rio de Janeiro, exercendo grande influência sobre a vida política da cidade.
} 
DANIELLE BASTOS LOPES - O Direito dos Índios no Brasil

conseguindo, eliminá-los (FRONTIN apud BESSA FREIRE, 2009, p. 187) ${ }^{5}$.

Assim, com as palavras "cabe assimilá-los e, não conseguindo, eliminá-los", a narração depreciativa tornava-se o símbolo da recémcriada república. A concepção de assimilação, que o republicano proferia na carta, trazia consigo a noção de incorporação do índio à sociedade nacional, rejeitando seus modelos sociais, crenças e influenciando as políticas legislativas posteriores. Somente a partir da Constituição de 1934 surgem as primeiras "linhas" dedicadas à existência dos índios em documento oficial. Redigido com escassas palavras, o artigo afirmava que os índios estavam submetidos à condição passageira de "silvícolas", propondo sua incorporação à sociedade nacional. "Art $5^{\circ}$ - Compete privativamente à União (...) XIX legislar sobre: (...) m) incorporação dos silvícolas à comunhão nacional". E foi a primeira a estabelecer que: "será respeitada a posse de terras de silvícolas que nelas se achem permanentemente localizados, sendoIhes, no entanto, vedado aliená-las" (CF., 1934, art. 5).

Assim, às vésperas da $2^{\circ}$ guerra mundial se instaurava no Brasil o regime ditatorial do "Estado Novo", liderado por Getúlio Vargas, que, após fechar o Congresso Nacional para elaboração de novas legislações, revogou a Carta de 1934, cedendo lugar à Constituição de 1937. Deste modo, em relação à questão indígena, o documento não previu, como os anteriores, a incorporação dos índios à sociedade nacional, mas também não mencionou nada em relação às suas diversidades étnicas. Em toda a extensão de seu longo texto, a Carta continha somente um único dispositivo ${ }^{6}$ que previa o tratamento dispensado às terras indígenas: "Art. $15^{\circ}$ - Será respeitada aos silvícolas a posse das terras em que se achem localizados em caráter permanente, sendo-lhes, porém, vedada a alienação das mesmas" (CF., 1937, art. 15).

No entanto, já no período do pós-golpe do Estado Novo (Era Vargas), foi elaborada a Constituição de 1946, considerada a mais avançada até aquele momento, votada em Assembleia Nacional Constituinte e promulgada no mês de setembro, sendo considerada notadamente um "avanço da democracia". A bancada Constituinte foi

\footnotetext{
${ }^{5}$ Carta da Sessão Magna do Centenário no dia 4 de Maio de 1900.

${ }^{6} \mathrm{O}$ artigo repete praticamente na íntegra o texto anterior redigido na Constituição de 1934.
} 
elaborada por Eurico Gaspar Dutra, então presidente e, neste sentido, o documento trazia de volta liberdades expressas na Constituição de 1934, que haviam sido retiradas do texto constitucional de 1937 devido ao golpe do Estado Novo. Dentre os dispositivos básicos que retornavam ao texto depois de um período ditatorial estavam: a igualdade de todos perante a lei; a inviolabilidade do sigilo de correspondência; a liberdade de consciência, de crença e de exercício de cultos religiosos; a separação dos três poderes (legislativo, executivo e judiciário); entre outros termos. Entretanto, mesmo com toda a campanha otimista que cercava a nova legislação, o texto de integração do índio à comunhão nacional da Carta de 1934 foi novamente repetido "Art. $5^{\circ}$. Compete à União: (...) XV - legislar sobre ((...) r) incorporação dos silvícolas à comunhão nacional" (CF., 1946, art. 5).

Poucos anos depois, a mesma perspectiva de integração foi predominantemente dispensada no tratamento dado aos índios pela Organização Internacional do Trabalho (OIT) a partir do documento proposto na Convenção $\mathrm{n}^{\circ} 107$, instaurada em 05 de junho de 1957. 0 texto foi o primeiro instrumento internacional relativo aos povos indígenas em contexto mundial. "Concernente à proteção e integração das populações indígenas e outras populações tribais e semitribais de países independentes" (OIT, 1957, p. 01).

Neste sentido, a OIT foi fundada em 1919 com o objetivo de promover a justiça social, sendo criada pela Conferência de Paz após a Primeira Guerra Mundial. O Brasil ratificou o instrumento de emenda da Convenção (EVANGELISTA, 2004). Dessa forma, a atenção internacional que se deu em relação à proteção dos povos indígenas passou a configurar uma preocupação na legislação indigenista não só do Brasil, mas de vários países da America Latina. Neste contexto, as discussões sucedidas a partir da Convenção 107 e sua difusão internacional influenciaram diretamente as constituições brasileiras que foram criadas após o documento.

Logo, duas décadas mais tarde, ocorre um novo governo ditatorial, o Golpe Militar de 1964, que outorgou em 24 de janeiro a Constituição de 1967. O poder foi centralizado nas mãos dos "Generais do Estado", o que permitia controle irrestrito sobre os produtos veiculados pela imprensa e na vida cotidiana do cidadão. Qualquer 
posicionamento contrário à política militarista era censurado, violentamente repreendido e tornado ilegal. Todavia, foi justamente nos anos mais sombrios de um Estado centralizador que a questão indígena recebeu maior atenção. Repetindo o descrito nas constituições anteriores de integração ${ }^{7}$ do índio à comunhão nacional, a carta de 1967 apresentou como diferencial, a proteção às terras ocupadas pelos "silvícolas", que passou a contar com uma garantia importante: a de serem incluídas entre os bens da União Federal (art. $4^{\circ}$, inc. IV8); e o mesmo texto inovou ao reconhecer aos índios o direito ao usufruto exclusivo dos recursos naturais. "Art. $186^{\circ}$ - É assegurada aos silvícolas a posse permanente das terras que habitam e reconhecido o seu direito ao usufruto exclusivo dos recursos naturais e de todas as utilidades nelas existentes" (CF., 1967, art. 186).

No entanto, como advertido por Egon Dionísio Heck (1996), cabe ressaltar que o interesse militar na promoção de políticas indigenistas consistia igualmente no interesse por uma exploração territorial, sobretudo nas áreas de fronteiras internacionais. Um significativo número dessas comunidades ocupava territórios interessantes para os planos "desenvolvimentistas" do governo, portanto, neutralizar, pacificar e controlar as terras ocupadas por essas populações transformaram- se em tarefas de urgência para os planos de base militar.

Assim, imbuídos do afã "rumo ao progresso", a Emenda Constitucional de 1969 seguiu os preceitos da política integracionista9 e dos interesses nos territórios ocupados por grupos indígenas. Com a Carta de 1969, as terras habitadas pelos índios passaram a ser "inalienáveis" (art. 198) e acrescentou também "a nulidade e a extinção dos efeitos jurídicos de qualquer natureza" aos que quisessem ocupar os territórios já habitados por populações indígenas.

Art. 198. As terras habitadas pelos silvícolas são inalienáveis nos têrmos que a lei federal determinar, a êles cabendo a sua posse permanente e ficando reconhecido o seu direito ao usufruto exclusivo das

\footnotetext{
7 “Art. $8^{\circ}$. Compete à União: (...) XVII - legislar sobre (...) o) incorporação dos silvícolas à comunhão nacional" (CF., 1967, art. 8 - grifos nossos).

8“"Art. $4^{\circ}$ - Incluem-se entre os bens da União: (...) IV - as terras ocupadas pelos silvícolas" (CF., 1967, art. 4 - grifos nossos).

9 "Art. $8^{\circ}$. Compete à União: (...) XVII - legislar sobre (...) o) nacionalidade, cidadania e naturalização; incorporação dos silvícolas à comunhão nacional” (CF., 1969, art. 8).
} 
DANIELLE BASTOS LOPES - O Direito dos Índios no Brasil

riquezas naturais e de tôdas as utilidades nelas existentes.

$\S 1^{0}$ Ficam declaradas a nulidade e a extinção dos efeitos jurídicos de qualquer natureza que tenham por objeto o domínio, a posse ou a ocupação de terras habitadas pelos silvícolas.

$\S 20$ A nulidade e extinção de que trata o parágrafo anterior não dão aos ocupantes direito a qualquer ação ou indenização contra a União e a Fundação Nacional do Índio (CF., 1969, art. 198).

Neste sentido, a Emenda daqueles finais dos anos 60 foi a última até a chegada da Carta de 1988. No entanto, dois documentos exteriores às constituições foram de fundamental importância para nosso entendimento sobre a legislação indigenista. O primeiro deles foi o Código Civil de 1916, que concebia ao índio a qualificação de "incapaz", nesta posição inseriam-se também os jovens entre 16 e 21 anos e os pródigos.

São incapazes relativamente a certos atos ou à maneira de exercê-lo: (...) III - os silvícolas. Parágrafo único. Os silvícolas ficarão sujeitos ao regime tutelar, o qual cessará à medida que forem se adaptando à civilização do País (BRASIL, 1993a, n. p. - grifos nossos).

Deste modo, somente em 2002 o Código foi revogado e um novo ${ }^{10}$ legislado. No atual, os índios foram retirados da condição de incapazes. $\mathrm{E}$, em seu artigo $3^{\circ}$, no Parágrafo único, afirma que: "a capacidade dos índios será regulada por legislação especial" (BRASIL, 2002, art. 3. § único).

Outra legislação de grande relevância, válida ainda atualmente, foi o Estatuto do Índio, aprovado em 19 de dezembro de 1973, sancionado pela Lei $n^{\circ} 6.001$. O documento passou a regular a situação jurídica das comunidades indígenas; ao legislar sobre os direitos civis e políticos que atingem os índios, o texto manteve a ideologia civilizatória e integracionista das constituições anteriores, adotando também o arcabouço jurídico tutelar. Quase 1/3 da lei (22 artigos) foi destinadas para regulamentação das atividades relativas às terras dos índios, cujo art. $65^{\circ}$ estabelece o prazo de cinco anos para a demarcação de todas as

\footnotetext{
${ }^{10}$ LEI N ${ }^{\mathrm{o}}$ 10.406, de 10 de Janeiro de 2002. Lei de Introdução ao Código Civil Brasileiro. Brasília: Senado Federal.
} 
terras indígenas, prazo este não cumprido até os dias atuais.

Sobre o Estatuto, em uma análise mais detalhada, cabe observar que no art. $20^{\circ}$ as terras indígenas são abertas a intervenções, por razões de "desenvolvimento" e "segurança nacional", possibilitando a transferência das mesmas. Evidenciando que não há, de fato, nenhuma

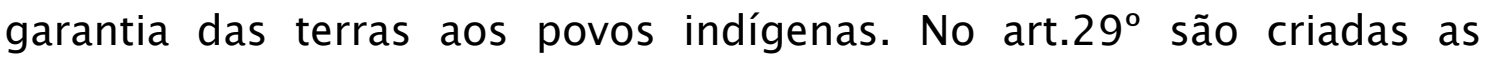
"colônias indígenas"11, projetos de referência do Estado. Com elas, se buscava equacionar o desafio da regularização das terras nas faixas de fronteiras, concentrando os índios em ocupações em torno de produção no estilo dos colonos. A demarcação de terras indígenas em região fronteiriça, de acordo com o pensamento militar, era uma ameaça, pois abria espaços para "fragmentação do território" e poderia ocasionar possibilidades para o surgimento de "países indígenas" (HECK, 1996) com territórios próprios. Além desse fato, no título "IV - dos bens e renda do patrimônio", se explicita o caráter empresarial que terá o órgão indigenista da FUNAl12 (Fundação Nacional do Índio) ao reaplicar a "renda" em atividades rentáveis, como a exploração das riquezas do subsolo (art. $45^{\circ}$ ), corte de madeira (art. $46^{\circ}$ ). Confirmando ainda a perspectiva integracionista, dando ao Estado poderes exclusivos sobre a assistência num regime de tutela.

Nestes termos, eram claras as contradições políticas do período. $\mathrm{Na}$ contramão do Estatuto, que previa um prazo de cinco anos para demarcação de terras, surgiam os "projetos de expansão e desenvolvimento", que pretendiam a ocupação extensa dos territórios amazônicos. Havia o discurso de proteção, mas somente mediado pelos moldes da tutela. Ou seja, o regime tutelar13, formalizado desde o Código Civil de 1916, teve assim seu dinamismo estabelecido por uma contradição básica e fundadora, conhecida como "o paradoxo da tutela", encerrando-se na seguinte incerteza: até onde o tutor existe para proteger o índio da sociedade que o cerca ou para defender os interesses da sociedade? Quando, neste sentido "é da própria natureza

\footnotetext{
${ }^{11}$ A proposta de colônia indígena foi incorporada ao Estatuto do Índio no seu art. $29^{\circ}$, que diz: "Colônia agrícola indígena é a área destinada à exploração agropecuária, administrada pelo órgão de assistência ao índio, onde conviviam tribos aculturadas e membros da comunidade nacional".

${ }^{12}$ A Fundação Nacional do Índio (FUNAI) foi criada em 1967, em substituição ao Serviço de Proteção aos Índios, fundado em 1910, sendo Marechal Cândido Mariano da Silva Rondon seu primeiro dirigente.

${ }^{13} \mathrm{O}$ caráter tutelar aos índios foi formalizado no Código Civil de 1916 e no Decreto ${ }^{\circ} 5.484$, de 1928 (PACHECO DE OLIVEIRA, 2006, p. 133).
} 
da tutela sua ambigüidade" (PACHECO DE OLIVERA, 2006, p. 25).

Assim, partindo destes demonstrativos, o que consideramos ao longo da trajetória das constituições é que temos: algumas leis, poucos espaços e amplas lacunas na relação dos "índios" versus representatividade no Estado. Assim, ao mesmo tempo em que se configuram nos remanescentes mais antigos de nosso território, na historiografia legislativa os índios representam ainda um dos mais novos e emergentes personagens.

\section{As Políticas Indigenistas e a caracterização do termo "índio"}

Neste contexto, o próprio termo "índio" traz consigo certa complexibilidade. Para o senso comum, como ressalta Bessa Freire (2000), índio é o sujeito de cabelos lisos e negros, olhos "cor de jambo", maçãs do rosto salientes, entre outras características (aspectos fenotípicos). No entanto, a concepção que utilizamos neste trabalho nada tem a ver com a proposta de um aspecto físico, mas sim com a representatividade de grupos que mantêm suas tradições.

De acordo com o antropólogo Darcy Ribeiro (1977), já nos anos 70 seria impossível uma definição de índio respaldada em critérios raciais (características físicas) e/ou em critérios somente culturais. Isso porque um critério puramente racial incluiria milhões de brasileiros que trazem traços físicos indígenas decorrentes da mestiçagem. E pautar-se por critérios culturais também não seria suficiente, já que existe um amplo arcabouço de traços culturais indígenas que fazem parte da vida cotidiana brasileira decorrente da "mestiçagem cultural"14. Sendo assim, dizermos que determinada pessoa é ou não é indígena por portar ou não um aspecto físico convencional é um problema mais complexo do que se apresenta. Neste sentido, o mais importante é que se entenda que quando falamos de grupos indígenas neste trabalho, estamos dissertando sobre pluralidades étnicas que residem no Brasil e foram descritas por cronistas e missionários desde o século XVI, sem

\footnotetext{
${ }^{14}$ Darcy relata que numa aldeia urubu-kaapor existia uma menina loura, de olhos claros, que era filha de uma índia e de um homem branco. Nascida na tribo, sem nunca ter tido nenhum contato com outras etnias, a menina falava e entendia o mundo através do dialeto daquela tribo. Era considerada pela tribo como sendo índia e se relacionava com os demais como um deles (RIBEIRO, 1977, p. 286).
} 
mencionar as inúmeras contribuições dos estudos antropológicos. Mesmo diante deste quadro, estes grupos indígenas representam a mais recente "descoberta" das constituições brasileiras e têm sua "diversidade" reconhecida há apenas 25 anos dentro de uma Constituição Nacional.

Portanto, sobre as políticas indigenistas, como vimos, os projetos de expansão territorial conflituam com áreas de ocupação indígena, o que tem ocorrido com mais frequência entre militares e índios. Para o "avanço civilizatório" das aspirações positivistas e "progressistas" seria necessário homogeneizar, unificar culturalmente o país, integrando os índios à sociedade brasileira. A legislação era constituída a partir de um paradigma Evolucionista ${ }^{15}$, onde o indígena foi situado em uma fase evolutiva primária, inferior à civilização nacional. Para o pensamento daquele momento, a condição de índio seria "transitória" e assim, a política indigenista teria por finalidade transformar o índio num trabalhador nacional, onde seriam adotados métodos e técnicas educacionais que controlariam o processo de homogeneização - era a chamada "Política de Integração" ou "integracionista" (CARNEIRO DA CUNHA, 1992).

Seguindo este pensamento, em 20 de junho de 1910, ocorre a criação do Serviço de Proteção aos Índios e Localização de Trabalhadores Nacionais (SPLINT), posteriormente chamado Serviço de Proteção aos Índios (SPI). Composto como parte integrante do Ministério da Agricultura, Indústria e Comércio (MAIC), o SPI fomentou significativas mudanças, a Igreja deixou de ter predominância no trabalho de assistência junto aos índios e além disso, com a criação do órgão federal, diminuiu o papel que os estados desempenhavam em relação às decisões sobre o destino das terras indígenas. A entidade procurava afastar a Igreja Católica da função catequisadora, seguindo o preceito republicano de separação Igreja - Estado.

Era a expansão do chamado "protecionismo indigenista", Marechal Cândido Mariano da Silva Rondon foi seu primeiro dirigente. O militar se

\footnotetext{
${ }^{15}$ No contexto da tradição evolucionista, que marcou a fase inicial da antropologia, o foco recaía sobre as formas e os sistemas de poder em sociedades "primitivas", cujas características deveriam ser comparadas e classificadas em relação ao sistema político das sociedades modernas, consideradas mais "evoluídas". Propunha-se, então, uma linha evolutiva das formas de organização política, que começava com a "horda primitiva" e chegava ao Estado moderno (RAMOS, 1991, p. 2).
} 
notabilizara pelos trabalhos de instalação de redes telegráficas no interior do país, durante os quais havia mantido contato pacífico com vários povos indígenas. As técnicas de pacificação adotadas por Rondon, evitando o confronto com índios em seus territórios, e escritas posteriormente na obra "Comissão Rondon", deram origem a muitas publicações científicas, tornando famosa a "Técnica de Pacificação".

No entanto, é curioso analisar que as táticas e técnicas desenvolvidas por Rondon filiam-se a uma longa genealogia que teve origem nos contatos dos jesuítas com as comunidades indígenas do século XVI. E neste sentido, ao se basear em noções militares, a estratégia rondoniana e de seus colaboradores objetivava proceder a "um grande cerco de paz" (SOUZA LIMA, 1995, p. 335) aos povos.

De acordo com Antonio Carlos de Souza Lima (1995), essa forma de poder exercida a partir do SPI(LTN) é intitulada "poder tutelar". Tratase de um poder estatizado, exercido sobre populações e territórios, que busca assegurar o monopólio dos procedimentos de controle. São seus produtos a formulação de um código jurídico acerca das populações indígenas e a implantação de uma malha administrativa instituidora de um "governo para os índios". O exercício do "poder tutelar" possui características específicas e é concebido como uma forma reelaborada com continuidades lógicas e históricas da "guerra de conquista". Neste caso, enquanto modelo analítico, a "conquista" é um empreendimento com distintas dimensões: fixação dos conquistadores nas terras conquistadas, redefinição das unidades sociais conquistadas, promoção de fissões e alianças no âmbito das populações conquistadas e objetivos econômicos.

Deste modo, passado quase meio século, por volta de 1957 o SPI entrou em processo de decadência administrativa. $O$ órgão passou a enfrentar problemas com os governos estaduais e grande parte de seus funcionários passaram a responder por acusações de improbidade administrativa, inclusive com relação ao patrimônio indígena, o que acabou por repercutir, nacional e internacionalmente, uma imagem negativa da instituição. Numa tentativa de "reorganização" das políticas indigenistas, é criada em 1967 a Fundação Nacional do Índio (FUNAl), órgão no qual, entre 1969 e 1974, uma série de novas políticas passaram a ser implementadas. 
O então Ministro do Interior, Rangel Reis, um de seus primeiros dirigentes, tomou como definição as categorias de: "índio aculturado" e índio "semi-aculturado"16. Os enquadramentos (aculturados, semiaculturados e isolados) consistiam no Projeto de Emancipação, ou seja, na criação de um instrumento jurídico para discriminar quem era índio de quem não o era. O que, de acordo com Eduardo Viveiros de Castro (2006), repercutia somente no propósito de retirar da responsabilidade tutelar do Estado os índios que teriam se "tornado" não índios; isto é, os indivíduos indígenas que já não apresentassem mais os estigmas de "indianidade" estimados "necessários" - "isso porque essa discussão, quem é índio, possui uma dimensão meio delirante ou alucinatória, como toda discussão onde o ontológico e o jurídico entram em processo de acasalamento" (VIVEIROS DE CASTRO, 2006, p. 10).

Neste caso, é interessante observar que foi somente a partir da Constituição de 1988 que se interrompeu jurídica e ideologicamente o projeto de "desindianização" ou "emancipação", legado de finais dos anos 60, ao reconhecer que o mesmo não se tinha completado. Nas palavras do autor "(...) foi assim que as comunidades em processo de distanciamento da referência indígena começaram a perceber que voltar a 'ser' índio - isto é, voltar a virar índio, podia ser interessante" (VIVEIROS DE CASTRO, 2006, p. 9).

\section{A Igreja e o surgimento do Movimento Social Indígena no Brasil}

Neste contexto, historicamente a postura da Igreja Católica esteve relacionada aos interesses dos grupos dominantes, impondo resistências às mudanças sociais. No momento da instalação do regime, em abril de 1964, setores da Igreja apoiaram o golpe. Havia o medo de uma possível adesão ao comunismo. No entanto, as posições surgidas no Il Concílio Vaticano, durante os anos 1960 - 1965, corroboradas nas Conferências Gerais do Episcopado Latino Americano de Medelín (1968) e Puebla (1969), realizaram certas revisões em sua postura

\footnotetext{
${ }^{16}$ Esta terminologia passou a ser utilizada em outros diversos conteúdos pelo poder executivo, porém sempre em detrimento dos direitos indígenas, procurando afastar a maioria dos índios do direito à terra coletiva e proteção especial. Eram, portanto, sem voz ou sem participação nas decisões de questões mais relevantes a respeito de seus interesses (SUESS, 1980, p. 45).
} 
conservadora.

No início da década de 70, a partir de outro tipo de engajamento político, ampliaram-se os trabalhos missionários, foram criadas as Comissões Pastorais (operária, da juventude, da terra e do índio) e as Comunidades Eclesiais de Base. Deste modo, as CEBs se constituíam em pequenos agrupamentos voluntários de cristão leigos para atuação na comunidade local, onde um dos enfoques principais da então surgida "nova linha pastoral" era aproximar setores da Igreja aos segmentos mais carentes da sociedade. Neste novo caminho de "opção preferencial pelos pobres", foi criada a então corrente da "Teologia da Libertação" e, neste sentido, como dito por Roberto Cardoso de Oliveira, "se antes o grande aliado do índio era o Estado, enquanto portador da ideologia rondoniana, agora o maior aliado passava a ser a Igreja, particularmente o seu setor progressista" (1988, p. 45).

Com o maior fechamento político do regime militar em 1968, começou a prevalecer na CNBB este setor, intitulado como "setor progressista" 17 da Igreja Católica. E, influenciado por esta perspectiva, em abril de 1972 foi fundado o Conselho Indigenista Missionário (CIMI), apresentando como proposta uma leitura diferenciada sobre o modo de vida dos povos indígenas - partia da concepção de "Encarnação" sintetizada na expressão "missão calada", na qual era valorizada a inserção no dia a dia das comunidades sem interferência em seus costumes e crenças, pois partia da premissa de que "a cultura de cada povo deveria ser respeitada" (SUESS, 1980).

Por conseguinte, o Cimi produziu o jornal Porantim que fora criado anos mais tarde, em 1978. Sua ideia de criação ocorreu em dezembro de 1976, quando José Bessa (fundador e editor do periódico) retornava ao Brasil, depois de quase oito anos de exílio passados no Uruguai, Peru e Chile. O periódico tornou-se o órgão de imprensa para informação, divulgação e denúncia da instituição. Era um dos únicos que

\footnotetext{
${ }^{17}$ De acordo com o padre Paulo Suess (1980), um dos membros da teologia da libertação, dentre seus representantes, os que mais se destacaram foram os religiosos D. Pedro Casaldáliga, D. Paulo Evaristo Arns, D. Helder Câmara, D. Balduíno, entre outros que juntamente com leigos protagonizaram importante função na organização popular da luta contra ditadura. Em relação às consequências destes posicionamentos, muitos militantes cristãos, padres e bispos sofreram perseguições, expulsão do país (exílio), atentados, sequestros e até mesmo assassinatos. D. Pedro Casaldáliga era o mais visado pelo regime, pois desde 1971 vinha publicando denúncias sobre a marginalização social da população amazônica.
} 
na época realizava frente contrária às informações estigmatizadas da grande imprensa.

Em entrevista18, José Ribamar Bessa Freire nos conta que seu início foi embrionariamente artesanal, com impressões mimeografadas e atingiam somente a região Amazônica; mas a partir de sua oitava edição, com o contato do Cimi em outros estados e a possibilidade de modernização nas formas de impressão, iniciou sua divulgação sobre os acontecimentos sucedidos aos índios em todo território nacional. Dessa forma, como nos narra seu editor, foi sendo gerada uma vasta rede de correspondentes espalhadas pelas aldeias do Brasil que

abasteciam o jornal com notas redigidas até em papel de embrulho, nas quais freqüentemente o lead vinha no final. O trabalho da redação era nesses casos de "cozinhar" o material recebido dando - Ihe tratamento jornalístico" (BESSA FREIRE, junho de 2011).

Assim, a partir do ideário de busca pela "autonomia indígena", concepção que trazia consigo a representação dos povos a partir de suas próprias lideranças, contrariando as normas do modelo tutelar, foram organizadas as Assembleias Indígenas do Cimi. Estas reuniam povos de diferentes estados brasileiros para encontros que discutiam desde os problemas locais de cada aldeia até questões mais amplas e genéricas, como o reconhecimento da diversidade, posse de terras, insatisfação com a política tutelar e etc.

Baseado no levantamento realizado por Ortolan Matos (apud LACERDA, 2008), de 1974 a 1984 foram realizadas cinquenta e sete Assembleias Indígenas em todo o país. De acordo com a autora, os índios foram se articulando independentemente e daí formando suas próprias bases de organização para a formação de um movimento indígena autônomo. Álvaro Tukano ${ }^{19}$ nos fala que: "Nasceu o movimento indígena nessas assembleias, porque para sermos movimento a gente

${ }^{18}$ JOSÉ RIBAMAR BESSA FREIRE. Entrevista concedida a Danielle Bastos Lopes. Rio de Janeiro, 12 de junho de 2011. Esta entrevista foi realizada para nossa dissertação de mestrado com o membro e diretor do Jornal Porantim. O editorial criado nos anos 70 é até hoje utilizado como fonte de pesquisa por antropólogos, estudantes e lideranças indígenas.

19 ÁLVARO FERNANDES SAMPAIO. Entrevista concedida a Danielle Bastos Lopes. Brasília (DF), 17 de julho de 2010. Álvaro Sampaio, mais conhecido como Álvaro Tukano (nome de sua etnia), é uma das lideranças mais antigas do movimento indígena e foi um dos fundadores e dirigentes da UNI (União das Nações Indígenas), criada em 1980. 
tem que ter parceiros" (ÁLVARO TUKANO, julho de 2010). Neste momento da entrevista, Álvaro conta que eram os índios que autonomamente iam se comunicando e formulando questões entre si "nenhum padre se intrometia, eles arrumavam o espaço e só, e nós discutíamos o que tinha para discutir" (ÁLVARO TUKANO, julho de 2010). Dessa forma, os passos do Cimi seguiam os preceitos do ideário de "missão calada" idealizado pela corrente da Teologia da Libertação.

Neste sentido, o movimento indígena consolida-se com a criação da União das Nações Indígenas (UNI)20, em 1980, já no momento de redemocratização do país. Seu processo de construção ocorreu no Seminário de Estudos Indígenas de Mato Grosso do Sul, realizado entre os dias 17 e 20 de abril de 1980, reunindo representantes de 15 etnias concentradas em sua maior parte nas regiões centro-oeste e sul. Neste, as 15 etnias ali presentes elegeram para primeira diretoria, Domingos Veríssimo Marcos (Terena) e como vice-presidente Marçal de Souza (Guarani).

Assim, entre os anos de 1981 a 1982, a entidade participou de variados encontros com instituições de âmbito nacional e internacional, entre elas, a conferência realizada pela UNESCO na Costa Rica, conferência da Organização das Nações Unidas (ONU) realizada na Suíça, o Congresso Indígena da Colômbia, entre outros. A presença dos líderes nestes encontros resultava progressivamente em maior visibilidade para o recém-criado movimento. Nas palavras de Álvaro Tukano: “(...) foi a partir da UNI que nós descobrimos índios no Brasil, índios fora do Brasil e fizemos uma grande articulação latino-americana e criamos o Conselho Mundial dos Povos Indígenas" (ÁLVARO TUKANO, julho de 2010).

\section{O movimento indígena na Constituinte}

Em finais dos anos 80 Ailton Krenak e Álvaro Tukano assumiram a

\footnotetext{
${ }^{20}$ A nomenclatura da UNI também foi oficializada, o que designou num entendimento entre outras jovens lideranças indígenas estudantes de Brasília que tinham fundado a UNIND, também intitulada União das Nações Indígenas, no mesmo ano; mas após um acordo oficial a sigla UNI se tornou a legítima representante.
} 
presidência da UNI ${ }^{21}$, quando a entidade participou ativamente de todo o processo ocorrido na Assembleia Nacional Constituinte. Em suas palavras,

\begin{abstract}
A UNI foi importante porque eu e Krenak nós passamos a intermediar os conflitos entre os dirigentes indígenas, e os coronéis, índios com os colonos, fazendeiros. E nossa vida tem sido de correria. Eu deixei de estudar para cuidar do Movimento Indígena, porque eu senti que essa era a minha vocação. Outros já não conseguem dirigir o movimento indígena sem salário, nem as próprias ONGs conseguem fazer. Mas fazer o movimento indígena é testar nossa capacidade de organização para articular nosso povo. E o movimento foi para buscar os líderes tradicionais, lutar contra a ditadura e fazer a nova Constituição. E hoje nós já estamos velhinhos (ÁLVARO TUKANO, julho de 2010).
\end{abstract}

Assim, no período pré-constituinte, que teve como base a expressiva participação popular, em 05 de julho de 1988 o relator da subcomissão, Bernardo Cabral, faz finalmente a entrega do Projeto de Constituição $B$, do projeto sairia a última votação para a nova Constituição. O projeto seguia o que havia sido votado, no entanto, na redação dada, renumerada como art. $234^{\circ}$, uma alteração no texto havia sido realizada, onde estava "São terras tradicionalmente ocupadas pelos índios, as por eles habitadas em caráter permanente, as utilizadas para suas atividades produtivas" (art. $269^{\circ}$ ) passou a ser "são terras tradicionalmente ocupadas pelos índios as por eles habitadas em caráter permanente, as que utilizam para atividades produtivas" (art. 234\%). Ou seja, substituía a expressão "as terras utilizadas" para "as que utilizam". A alteração não agradou muito o movimento indígena, pois afirmavam que colocando a expressão no tempo presente, "as que utilizam", poderia excluir grupos que não estivessem, no momento, utilizando as terras por motivo de invasão ou outros afins.

No entanto, o dia da votação se aproximava, e no início de agosto chegava a Brasília uma caravana de povos vindos do nordeste, formada por representantes dos povos Potiguara (PB), Fulni-ô (PE), Kapinawá (PE),

\footnotetext{
${ }^{21}$ Neste contexto, a UNI se encerrou pouco tempo depois de votada a nova Constituição, as regionais da se desintegraram à medida que seus líderes voltaram para uma atuação visando atender aos interesses específicos de suas aldeias.
}

Espaço Ameríndio, Porto Alegre, v. 8, n. 1, p. 83-108, jan./jun. 2014. 
Xukuru (PE), Geripankó (AL), Xukuru-Kariri (AL), Karapotó (AL) e Xokó (SE). A caravana nordestina juntou-se aos Kayapó ali presentes desde o primeiro turno de votações e mais uma centena de indígenas chegados do sul, centro-oeste e norte do país, a exemplo dos Kaingang, Guarani, Xavante e Xerente ${ }^{22}$. Divididos em grupos, os representantes de cada etnia voltaram a percorrer os gabinetes dos parlamentares e a executar suas danças e rituais nos corredores do Congresso (LACERDA, 2008; BASTOS LOPES, 2011).

Finalmente, em 30 de agosto, o capítulo "Dos índios" era submetido ao $2^{\circ}$ turno das votações no Plenário. Na ocasião, a maior atenção era para a modificação realizada no texto do agora chamado artigo $234^{\circ}$, que passou a empregar o verbo no tempo presente, "utilizam" em vez de "utilizadas", em relação às terras permanentemente ocupadas. Por se tratar de um acordo entre os vários constituintes, o relator acabou posicionando-se favorável à alteração para forma original do texto. Os demais dispositivos pertencentes ao capítulo foram aprovados. E exterior ao capítulo "Dos índios", outros artigos, como o art. $210^{\circ}$, que garantiu às comunidades indígenas a utilização de sua língua materna e processos próprios de aprendizagem, também foram aprovados.

Contudo, fato curioso neste processo, é que infelizmente o último ato não pôde ser testemunhado pelas lideranças indígenas; embora muitas houvessem retornado a Brasília para acompanhá-lo, somente Aílton Krenak ${ }^{23}$, que possuía autorização especial para ingressar nas galerias do Plenário, conseguiu assistir à votação. A ausência dos grupos indígenas foi lamentada inclusive pelos constituintes: Tadeu França (PDT-PR), Benedita da Silva (PT-RJ), Haroldo Lima (PCdoB - BA), Sólon Reis (PTB-SP), entre outros. E, portanto, em relação ao capítulo "Dos Índios", o texto pós-votação foi assim definido:

CAPÍTULO VIII

Dos Índios

Art. 231. São reconhecidos aos índios sua organização social, costumes, línguas, crenças e tradições, e os

\footnotetext{
${ }^{22}$ Como ocorrera no primeiro turno de votação, a mobilização indígena foi apoiada pelo Cimi, que providenciou transporte e condução em Brasília.

${ }^{23}$ Aílton Krenak obteve autorização especial, pois era o presidente da União das Nações Indígenas na época (BASTOS LOPES, 2011).
} 
direitos originários sobre as terras que tradicionalmente ocupam, competindo à União demarcá-las, proteger e fazer respeitar todos os seus bens.

$\S 1.0$ São terras tradicionalmente ocupadas pelos índios as por eles habitadas em caráter permanente, as utilizadas para suas atividades produtivas, as imprescindíveis à preservação dos recursos ambientais necessários a seu bem-estar e as necessárias a sua reprodução física e cultural, segundo seus usos, costumes e tradições.

$\S 2.0$ As terras tradicionalmente ocupadas pelos índios destinam-se a sua posse permanente, cabendo-lhes 0 usufruto exclusivo das riquezas do solo, dos rios e dos lagos nelas existentes.

$\S 3.0$ O aproveitamento dos recursos hídricos, incluídos os potenciais energéticos, a pesquisa e a lavra das riquezas minerais em terras indígenas só podem ser efetivados com autorização do Congresso Nacional, ouvidas as comunidades afetadas, ficando-lhes assegurada participação nos resultados da lavra, na forma da lei.

$\S 4 .^{\circ}$ As terras de que trata este artigo são inalienáveis e indisponíveis, e os direitos sobre elas, imprescritíveis. $\S 5 .^{\circ}$ É vedada a remoção dos grupos indígenas de suas terras, salvo, ad referendum do Congresso Nacional, em caso de catástrofe ou epidemia que ponha em risco sua população, ou no interesse da soberania do País, após deliberação do Congresso Nacional, garantido, em qualquer hipótese, o retorno imediato logo que cesse o risco.

$\S 6.0$ São nulos e extintos, não produzindo efeitos jurídicos, os atos que tenham por objeto a ocupação, o domínio e a posse das terras a que se refere este artigo, ou a exploração das riquezas naturais do solo, dos rios e dos lagos nelas existentes, ressalvado relevante interesse público da União, segundo o que dispuser lei complementar, não gerando a nulidade e a extinção direito a indenização ou a ações contra a União, salvo, na forma da lei, quanto às benfeitorias derivadas da ocupação de boa-fé.

$\S 7.0$ Não se aplica às terras indígenas o disposto no art. $174, \S 3.0$ e $4.0^{\circ}$.

Art. 232. Os índios, suas comunidades e organizações são partes legítimas para ingressar em juízo em defesa de seus direitos e interesses, intervindo o Ministério Público em todos os atos do processo.

E assim, como narra Rosane Lacerda (2008), os índios festejaram subindo a rampa do Congresso Nacional, exaltando que pela primeira 
vez na história do constitucionalismo a elaboração de uma Carta havia sido realizada a partir da participação dos povos indígenas.

\section{Considerações finais}

Por fim, ao analisar seu histórico, consideramos que entre os ganhos da Constituição de 1988 estão: (1) o reconhecimento das organizações indígenas, além dos próprios índios e suas comunidades, como parte legítima para ingressar em juízo em defesa dos seus direitos; (2) o reconhecimento da diversidade cultural existente no Brasil a partir do reconhecimento das línguas indígenas e dos povos indígenas com sua cultura, costumes, crenças e tradições; (3) uma educação diferenciada para cada povo indígena, e principalmente com um processo próprio de aprendizagem; (4) o reconhecimento do direito à terra; (5) a vinculação da exploração mineral a uma autorização do Congresso Nacional; (6) a proteção e demarcação das terras indígenas como obrigações do Estado e (7) a nulidade de atos que tenham como objeto o domínio e posse das terras indígenas.

No entanto, alguns outros pontos positivos, como o reconhecimento do Brasil como uma nação pluriétnica e o direito do índio ao usufruto do subsolo, aprovados no início das discussões, ainda nos textos iniciais da Subcomissão e da Comissão da Ordem Social Constituinte, foram perdidos ao longo do processo. A expressão "pluriétnica" para falar sobre nação acabava por ser um tabu, já que a ideologia do Estado Nação compreendia a "nacionalidade" como um desejo de unidade coesa e uniforme. E, deste modo, ainda que tenha sido um grande avanço para as comunidades o seu direito ao usufruto do solo, o "subsolo", como expresso por Bessa Freire (2009), ainda era uma questão "delicada" para deixar nas "mãos dos índios", já que interesses de grandes corporações nacionais e internacionais visavam a exploração de suas reservas.

Portanto, para chegada deste momento, observa-se que mortes foram ocasionadas, violências e torturas foram sofridas; índios vestiram-se de "terno e gravata" tornando-se "lideranças políticas indígenas", viajaram até os centros urbanos, aprenderam o português, o 
que até então era inesperado para muitas comunidades, já que havia um distanciamento muito grande entre as aldeias e a escola tradicional; organizaram um movimento indígena; os parlamentares tiveram relevantes contribuições nos momentos de fala dos antropólogos e indigenistas que passaram pelo Congresso Nacional e a própria Igreja (re) criou o seu processo de relacionamento com os índios. Portanto, por ora, fechamos o estudo deste processo de representação dos povos indígenas nas constituições, entendendo que obviamente existe uma grande margem entre o que é legislado e a realidade, mas o reconhecimento destes direitos na atual Constituição foi um passo importante e necessário para o que hoje impulsiona o movimento indígena no Brasil.

\section{Referências bibliográficas}

ANDERSON, Benedict. Imagined Communities: revised Edition. Londres: Verso, 1991.

BANTON, Michel. A idéia de raça. Lisboa: Edições 70, 1977.

BEOZZO, José Oscar. Leis e Regimentos das Missões: Política Indigenista no Brasil. São Paulo: Ed. Loyola, 1983.

BASTOS LOPES, Danielle. O Movimento Indígena na Assembléia Nacional Constituinte (1984-1988). 2011. 184 f. Dissertação (Mestrado em História Social) Universidade do Estado do Rio de Janeiro, UERJ, Rio de Janeiro, [2011].

CARDOSO DE OLIVEIRA, Roberto. A crise do indigenismo. Campinas: Ed. Unicamp, 1988.

CARNEIRO DA CUNHA, Manoela. História dos índios no Brasil. São Paulo: Companhia das Letras/Secretaria Municipal de Cultura/FAPESP, 1992.

CEDI: Centro Ecumênico de Documentação e Informação. Povos Indígenas no Brasil: 1987/1988/1989/1990. São Paulo: CEDI, 1991. (Série Aconteceu Especial, n. 18).

CHAUÍ, Marilena de Souza. O ceticismo sobre a Constituinte. In: SALINAS FORTES, Luiz Roberto; NASCIMENTO, Milton Meira do (Org.). A Constituinte em debate. São Paulo: Ed. Sofia, 1987. p. 157-165. 
DEPARIS, Sidiclei Roque. União das Nações Indígenas (UNI): Contribuição ao movimento indígena no Brasil (1980-1988). 2007. 126 f. Dissertação (Mestrado em História) - Universidade Federal Grandes Doutorados - UFGD, Grandes Doutorados, [2007].

EVANGELISTA, Carlos Augusto Valle. Direitos Indígenas: o debate na Constituinte de 1988. 2004. 76 f. Dissertação (Mestrado em História) - Universidade Federal do Rio de Janeiro - UFRJ, Rio de Janeiro, [2004].

FONTES, Virgínia. Sociedade Civil no Brasil Contemporâneo: lutas sociais e luta teórica na década de 1980. In: LIMA, Júlio; NEVES, Lúcia (Org.). Fundamentos da Educação Escolar do Brasil Contemporâneo. Rio de Janeiro: Ed. Fiocruz, 2006. p. 161-178.

BESSA FREIRE, José Ribamar. Cinco idéias equivocadas sobre o índio. Cenesch: Revista do Centro de Estudos do Comportamento Humano, Manaus, v. 1, p. 17-33, 2000 .

Uma Constituição Legal para os índios? In: VERSIANI, Maria Helena; MACIEL, Ira; SANTOS, Núbia Melhem (Org.). Cidadania em Debate. Rio de Janeiro: Ed. Museu da República, 2009. p. 224-229.

GELLNER, Ernest. Nations and Nationalism. Oxford: Blackwell Publishers, 1983.

GOHN, Maria da Glória. Movimentos sociais no início do século XXI: antigos e novos atores sociais. Petrópolis: Vozes. 2003.

HECK, Egon Dionísio. Os índios e a caserna: política indigenista dos governos militares 1964-1985. Campinas: Ed. Unicamp, 1996.

JURUNA, Mario; HOHLFELDT, Antonio; HOFFMANN, Assis. O gravador de Juruna. Porto Alegre: Ed. Mercado Aberto, 1982.

LACERDA, Rosane. Os povos indígenas e a Constituinte (1987-1988). Brasília: Ed. do Cimi, 2008.

LE GOFF, Jacques. História e Memória. Campinas: Ed. Unicamp, 1990.

MISSÃO RONDOM. Brasília: Senado Federal/Conselho Editorial, 2003.

OIT. Convenção 107. 1957. Disponível em: http://www.oitbrasil.org.br/ . Acesso em: 27 jun. 2014.

PACHECO DE OLIVEIRA, João. Ensaios em Antropologia Histórica. Rio de Janeiro: Ed. UFRJ, 1999.

A presença indígena na formação do Brasil. Brasília: Secretaria de Educação 
Continuada, Alfabetização e Diversidade (Secad)/LACED/Museu Nacional, 2006.

RAMOS, Alcida Rita. Os Direitos do índio no Brasil: na encruzilhada da cidadania. Brasília: DAN/UnB, 1991. (Série Antropologia).

RIBEIRO, Darcy. Os índios e a civilização: a integração das populações indígenas no Brasil moderno. São Paulo: Companhia das Letras, 1977.

SOUZA LIMA, Antonio Carlos de. Um Grande Cerco de Paz: Poder Tutelar, Indianidade e Formação do Estado no Brasil. Petrópolis: Ed. Vozes, 1995.

SUESS, Paulo. Em Defesa dos Povos Indígenas: documentos e legislação. São Paulo: Edições Loyola, 1980. p 45.

VIVEIROS DE CASTRO, Eduardo. No Brasil, todo mundo é índio, exceto quem não é. In: ISA. Povos Indígenas no Brasil: 2001-2005. São Paulo: Instituto Socioambiental, 2006.

\section{Fontes}

\section{1- Entrevistas}

ÁLVARO FERNANDES SAMPAIO. Entrevista concedida a Danielle Bastos Lopes. Brasília (DF), 17 de julho de 2010.

JOSÉ RIBAMAR BESSA FREIRE. Entrevista concedida a Danielle Bastos Lopes. Rio de Janeiro, 12 de junho de 2011.

\section{2- Leis, Legislações e Regimentos}

BRASIL. Assembléia Nacional Constituinte. (Atas Das Comissões) VII - Comissão da Ordem Social. Brasília: Senado Federal. Centro Gráfico do Senado Federal, 1987a.

Assembléia Nacional Constituinte. Projeto de Constituição (A) da Comissão de Sistematização. v. 251. Brasília: Senado Federal. Centro Gráfico do Senado Federal, $1987 b$.

Assembléia Nacional Constituinte. Comissão da Ordem Social. VII-c Subcomissão dos Negros, Populações Indígena, Pessoas Deficientes e Minorias. Anteprojeto e Relatório. v. 196. Brasília: Senado Federal. Centro Gráfico do Senado Federal, 1987c.

Diário da Assembléia Nacional Constituinte - Subcomissão do Negro, Populações Indígenas, Pessoas Deficientes e Minorias, (Comissão da Ordem Social). Brasília: Senado Federal. Centro Gráfico do Senado Federal, 1987d. 
Código Civil de 1916. Brasília: Senado Federal / Sub Secretaria de Edições Técnicas, 1993a.

Código Civil de 2002. Brasília: Senado Federal / Sub Secretaria de Edições Técnicas, $1993 b$.

Regimento Interno. Assembléia Nacional Constituinte. Vol. 330, (Resolução n02/87). Brasília: Senado Federal / Sub Secretaria de Edições Técnicas, 1993c.

Constituição de 1824. Brasília: Senado Federal / Sub Secretaria de Edições Técnicas, $1993 \mathrm{~d}$.

Constituição de 1891. Brasília: Senado Federal / Sub Secretaria de Edições Técnicas, 1993e.

Constituição de 1934. Brasília: Senado Federal / Sub Secretaria de Edições Técnicas, $1993 f$.

Constituição de 1946. Brasília: Senado Federal/ Sub Secretaria de Edições Técnicas, 1993g.

Constituição de 1967. Brasília: Senado Federal / Sub Secretaria de Edições Técnicas, $1993 \mathrm{~h}$.

Emenda Constitucional de 1969. Brasília: Senado Federal / Sub Secretaria de Edições Técnicas, 1993 i.

Constituição de 1988. Brasília: Senado Federal / Sub Secretaria de Edições Técnicas, 1993j. 